\title{
EFFECT OF GUM CHEWING ON AIR SWALLOWING, SALIVA SWALLOWING AND BELCHING
}

\author{
Ana Cristina Viana da SILVA, Lilian Rose Otoboni APRILE and Roberto Oliveira DANTAS
}

Received 3/3/2015

Accepted 27/4/2015

ABSTRACT - Background - Eructation is a physiologic event which allows gastric venting of swallowed air and most of the time is not perceived as a symptom. This is called gastric belching. Supragastric belching occurs when swallowed air does not reach the stomach and returns by mouth a short time after swallowing. This situation may cause discomfort, life limitations and problems in daily life. Objective - Our objective in this investigation was to evaluate if gum chewing increases the frequency of gastric and/or supragastric belches. Methods - Esophageal transit of liquid and gas was evaluated by impedance measurement in 16 patients with complaint of troublesome belching and in 15 controls. The Rome III criteria were used in the diagnosis of troublesome belching. The esophageal transit of liquid and gas was measured at $5 \mathrm{~cm}, 10 \mathrm{~cm}, 15 \mathrm{~cm}$ and $20 \mathrm{~cm}$ from the lower esophageal sphincter. The subjects were evaluated for 1 hour which was divided into three 20-minute periods: (1) while sitting for a 20-minute base period; (2) after the ingestion of yogurt $(200 \mathrm{~mL}, 190 \mathrm{kcal})$, in which the subjects were evaluated while chewing or not chewing gum; (3) final 20-minute period in which the subjects then inverted the task of chewing or not chewing gum. In gastric belch, the air flowed from the stomach through the esophagus in oral direction and in supragastric belch the air entered the esophagus rapidly from proximal and was expulsed almost immediately in oral direction. Air swallows were characterized by an increase of at least $50 \%$ of basal impedance and saliva swallow by a decrease of at least $50 \%$ of basal impedance, that progress from proximal to distal esophagus. Results - In base period, air swallowing was more frequent in patients than in controls and saliva swallowing was more frequent in controls than in patients. There was no difference between the medians of controls and patients in the number of gastric belches and supragastric belches. In six patients, supragastric belches were seen at least once during the 20-minute base period. None of the controls had supragastric belches. In the control group, the ingestion of yogurt caused no significant alteration in the number of air swallows, saliva swallows, gastric belches and supragastric belches. In the patient group, there was an increase in the number of air swallows. If the subjects were chewing gum during this 20-minute period, there was an increase in the number of saliva swallows in both groups, without alterations of the number of air swallow, gastric belches and supragastric belches. There was no alteration in the number of the saliva swallows, air swallows, gastric belches and supragastric belches in both groups for subjects who did not chew gum in the 20-40 minute period after yogurt ingestion. When the subjects were chewing the gum, there was an increase in saliva swallows in the control and patients groups and in air swallows in the patients group. Conclusion - Gum chewing causes an increase in saliva swallowing in both patients with excessive belching and in controls, and an increase in air swallowing in patients with excessive belching 20 minutes after yogurt ingestion. Gum chewing did not increase or decrease the frequency of gastric or supragastric belches.

HEADINGS - Eructation. Aerophagy. Deglutition. Esophagus. Saliva.

\section{INTRODUCTION}

A common physiological situation involves a variable volume of air swallowed during drinking and eating ${ }^{(2)}$. Eructation is a physiologic event which allows gastric venting of this swallowed air and most of the time is not perceived as a symptom ${ }^{(11,14)}$.

Some individuals have problems with excessive air swallowing, called aerophagia, which causes repetitive gastric and/or supragastric belching ${ }^{(18)}$ that may cause discomfort, life limitations, problems in daily life and impair the quality of life ${ }^{(14)}$. Excessive belching is a symptom often seen in patients with functional dyspepsia and gastroesophageal reflux disease, but isolated excessive belching may be seen in a small number of patients ${ }^{(1)}$.

Gastric belching is the result of the release of accumulated intragastric air associated with lower esophageal sphincter relaxation. Supragastric belching occurs when swallowed air does not reach the stomach and returns by mouth a short time after swallowing ${ }^{(2,12,13,18)}$. 
Chewing gum is used to a varying degree to protect teeth $^{(5,6,8)}$ and improve the return of bowel function after abdominal surgery ${ }^{(7,23)}$, but may cause side effects as chronic headache in adolescents ${ }^{(25)}$, increase gastric secretion ${ }^{(9)}$ and suppression in initial gastric emptying ${ }^{(16)}$.

Gum chewing increases the flow of saliva ${ }^{(6,17)}$, which helps to neutralize and wash away the acids that are produced when food is broken down by the bacteria in plaque on the teeth ${ }^{(24)}$. The increase in saliva flow could increase the frequency of saliva swallowing, but also could increase the frequency of air swallowing, worsening the discomfort caused by gastric and/ or supragastric belching. Our objective in this investigation was to evaluate the effect of gum chewing on the frequency of air swallows, saliva swallows, gastric belches and supragastric belches in patients with the complaint of troublesome belching and controls. Our hypothesis is that gum chewing may increase aerophagia and belching frequency.

\section{METHODS}

Esophageal transit of liquid and gas was evaluated, in an experimental investigation, by impedance in 16 patients with troublesome belching and in 15 controls. These individuals had previous investigation of esophageal motility, when no difference in esophageal contractions was found in patients with troublesome belching compared to controls ${ }^{(20)}$. The project was approved by the Human Research Committee of the University Hospital of Ribeirão Preto, Brazil. All volunteers and patients gave written informed consent to participate in the investigation.

The patients with troublesome belching were six men and 10 women (age: $25-57$ years; mean $46.2 \pm 8.2$ years). They complained of excessive belching at least three times during the day, more than three times a week, for more than 6 months, causing problems at work and impairment of their family and social life. Eleven patients also had heartburn and gastric pain, three had heartburn and depression and two did not have other symptoms. Before inclusion in the study, patients were asked about frequency, importance of the belches and previous treatment. The diagnosis takes into consideration the Roma III criteria $^{(21,22)}$. Patients did not have relief from symptoms with proton pump inhibitors, prokinetics or antidepressants, used for more than 6 months. The control group had six men and nine women (age: $25-58$ years; mean $46.2 \pm 7.8$ years). They did not have troublesome belches, heartburn or any complaints in the digestive and respiratory tracts. Subjects of both groups did not have dysphagia, neurologic or endocrinal diseases. Controls and patients were recruited by advertisement from within our institution.

The esophageal transit of gas and liquid were measured by impedance with a catheter of the Sandhill Scientific Manometry System (Highlands Ranch, CO, USA) that incorporates five pressure and four impedance-measuring segments. In this investigation we used only the impedance sensors. The impedance-measuring segments of the catheter consisted of pairs of metal rings placed $2 \mathrm{~cm}$ apart. The signal from the catheter was transferred to an amplifying and digitalizing interface (Sensor PAC-Z, Sandhill Scientific Inc), recorded and stored using the dedicated software Insight Acquisition (Sandhill Scientific Inc) and Bio-View Analysis (Sandhill Scientific Inc). The impedance alteration during the examination was analyzed as previously described ${ }^{(2,12,13)}$. In gastric belch, the air flowed from the stomach through the esophagus in oral direction, and in supragastric belch, the air entered the esophagus rapidly from proximal and was expulsed almost immediately in oral direction. Air swallows were characterized by an increase of at least $50 \%$ of the impedance, and saliva swallow by a decrease of at least $50 \%$ of the impedance, which progress from proximal to distal esophagus.

The volunteers and patients were studied while sitting after 12 hours of fasting. The catheter was introduced through the nose until the distal pressure sensor of the catheter, used as reference of position, registered the lower esophageal sphincter (LES) pressure. The impedance was registered at 5, 10, 15, and $20 \mathrm{~cm}$ from the LES. After 5 minutes of stabilization, the impedance monitoring for the presence of gastric belches, supragastric belches, saliva and air swallows was recorded for 1 hour, divided into three 20-minute periods. The first twenty minutes was the base period. After the base period, the individuals ingested by straw $200 \mathrm{~mL}$ of yogurt (Laticinios Carolina Ltda, Ribeirão Claro PR, Brazil), strawberry flavor with 190 kcal. Following yogurt ingestion, each volunteer and patient was randomized to chew or not to chew for a 20-minute period chewing gum (Cadbury Adams Bauru SP, Brazil) peppermint flavor with $5 \mathrm{kcal}$, in which upon completion of the period, the task of chewing or not chewing gum was inverted for an additional 20-minute period. The number of air swallows, saliva swallows, gastric belches and supragastric belches were measured during the base period, after the meal during the first 20-minute period (task: with or without gum chewing), and during the second 20-minute period (task inverted). The results are expressed as the number of episodes during the base period and the increase or decrease in the number of episodes related to the base period after the yogurt ingestion.

Statistical analysis was done by the Center of Quantitative Analysis of the Medical School of Ribeirão Preto USP (CEMEQ) using a linear model with mixed effects ${ }^{(19)}$. The model was adjusted using the Proc Mixed feature of the SAS software package version $9^{(15)}$. The results are reported as median and limits, unless otherwise stated. The differences were considered significant when $P<0.05$ in a two-tailed statistical analysis.

\section{RESULTS}

During the 20-minute base period, air swallowing was observed to be more frequent in patients than in controls $(P<0.01)$ and that saliva swallowing was more frequent in controls than in patients $(P=0.01$, Table 1$)$. There were no differences between the medians of controls and patients in the number of gastric belches and supragastric belches $(P>0.05)$. In six patients, supragastric belches were seen at least once during the 20-minute base period. None of the controls had supragastric belches. 
TABLE 1. Evaluation of controls $(n=15)$ and patients with complain of excessive belching ( $n=16)$ during 20 minutes of base registration, expressed by median and limits of the number of episodes

\begin{tabular}{lccccc}
\hline & \multicolumn{2}{c}{ Controls } & \multicolumn{2}{c}{ Patients } & \multirow{2}{*}{$\boldsymbol{P}$} \\
\cline { 2 - 5 } & Median & Limits & Median & Limits & \\
\hline Air swallowing & 1 & $0-9$ & 4 & $0-61$ & $<0.01$ \\
Saliva swallowing & 29 & $3-52$ & 15 & $0-64$ & 0.01 \\
Gastric belching & 2 & $0-6$ & 1 & $0-3$ & $>0.05$ \\
Supragastric belching & 0 & $0-0$ & 0 & $0-9$ & $>0.05$ \\
\hline
\end{tabular}

The ingestion of yogurt caused no significant alteration in the number of saliva swallows (Figure 1), air swallows (Figure 2), gastric belches and supragastric belches (Table 2) in the control group. In the patient group, there was an increase in the number of air swallows (Figure 2, $P=0.03$ ). If the subjects were gum chewing during this 20-minute period, there was an increase in the number of saliva swallows $(P=0.01)$ in both groups (Figure 1), without alterations of the number of air swallows (Figure 2), gastric belches and supragastric belches (Table 2).

In the period from twenty minutes to forty minutes af-

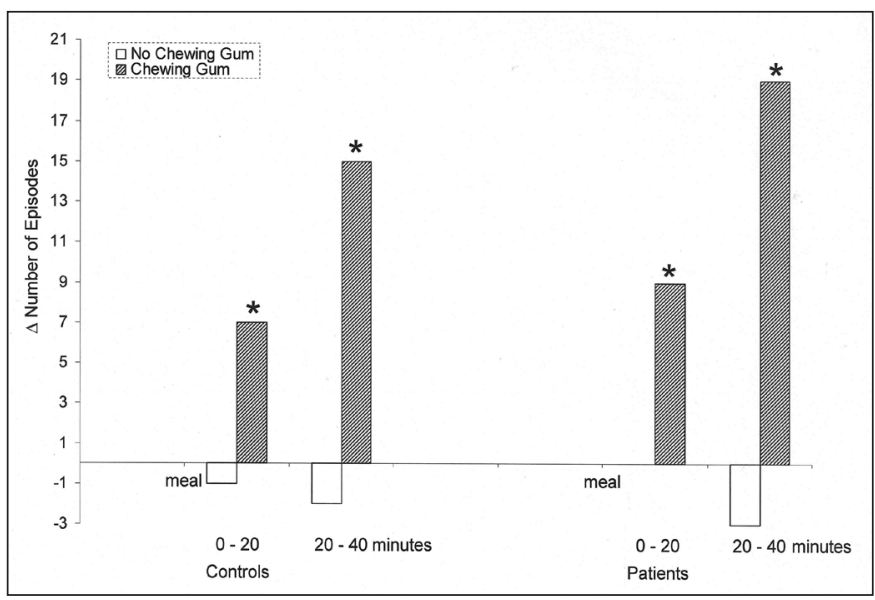

FIGURE 1. Number of saliva swallow episodes, related to the base period, in patients and controls after yogurt ingestion (meal), with and without gum chewing. A negative number represents a decrease in the number of episodes and a positive number an increase in the number of episodes. $* P \leq 0.01$ vs base period ter yogurt ingestion, when the subjects did not chew gum, there was no alteration in the number of the saliva swallows (Figure 1), air swallows (Figure 2), gastric belches and supragastric belches (Table 2) in either group. When the subjects were gum chewing, there was an increase in saliva swallows in the control and patient groups (Figure $1, P<0.01$ ) and in air swallows in the patient group (Figure 2, $P<0.01$ ).

\section{DISCUSSION}

With the introduction of the impedance recording technique in the evaluation of esophageal physiology, it was possible to register the passage of air through the esophagus, either in aboral or oral direction, with a differentiation between gastric and supragastric belching ${ }^{(12,13)}$. Gastric belching is a physiologic phenomenon which helps to eliminate gas accumulated inside the upper digestive tract. Part of the swallowed air goes to the bowel and part is eliminated from the stomach by eructation ${ }^{(13)}$. In a supragastric belch, the swallowed air only goes inside the esophagus and is immediately eliminated.

Excessive belching is a behavioral disorder associated with anxiety, stressful event, obsessive compulsive disorder and

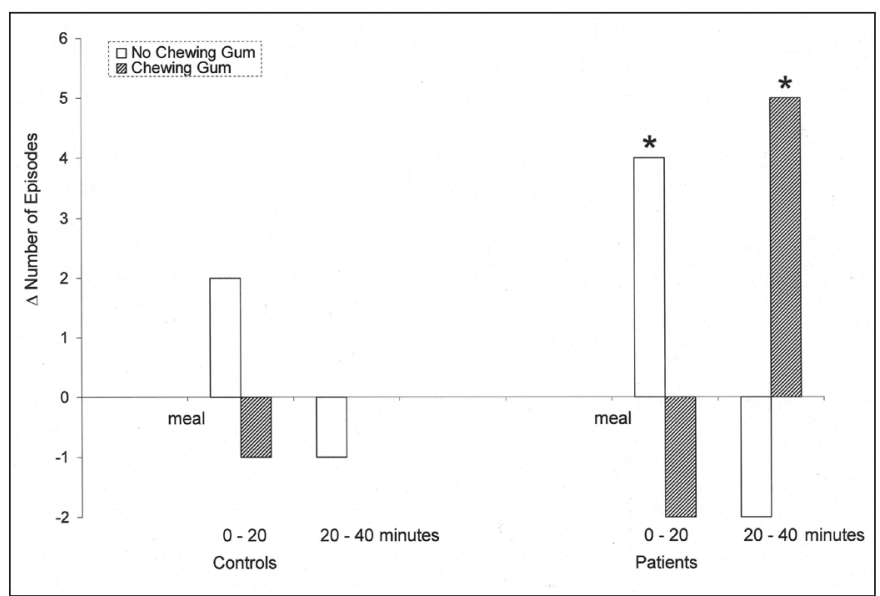

FIGURE 2. Number of air swallow episodes, related to the base period, in patients and controls after yogurt ingestion (meal), with and without gum chewing. A negative number represents a decrease in the number of episodes and a positive number an increase in the number of episodes. $* P \leq 0.01$ vs base period

TABLE 2. Response of the number of supragastric and gastric belching, related to the base period, in controls and patients with complaint of excessive belching, after 0-20 minutes and 20-40 minutes after the ingestion of yogurt

\begin{tabular}{|c|c|c|c|c|c|c|c|c|}
\hline & \multicolumn{4}{|c|}{0 - 20 minutes } & \multicolumn{4}{|c|}{20 - 40 minutes } \\
\hline & \multicolumn{4}{|c|}{ Chewing Gum } & \multicolumn{4}{|c|}{ Chewing Gum } \\
\hline & \multicolumn{2}{|c|}{ No } & \multicolumn{2}{|c|}{ Yes } & \multicolumn{2}{|c|}{ No } & \multicolumn{2}{|c|}{ Yes } \\
\hline & Median & Limits & Median & Limits & Median & Limits & Median & Limits \\
\hline \multicolumn{9}{|c|}{ Supragastric belching } \\
\hline Controls & 0 & $0-0$ & 0 & $0-0$ & 0 & $0-0$ & 0 & $0-0$ \\
\hline Patients & 0 & $-4-17$ & 2 & $1-5$ & 1 & $0-4$ & 1 & $-4-47$ \\
\hline \multicolumn{9}{|c|}{ Gastric belching } \\
\hline Controls & 1 & $-1-2$ & 1 & $-3-4$ & 0 & $-4-0$ & 1 & $-1-3$ \\
\hline Patients & 1 & $-1-2$ & 0 & $0-1$ & 0 & $-2-3$ & 0 & $-3-1$ \\
\hline
\end{tabular}


bulimia $^{(3,10)}$. The treatment of the symptomatic situation, most of the time caused by supragastric belches that are associated with the most severe belch complaints ${ }^{(13)}$, involves explanation, creating awareness of belching mechanism, breathing and vocal exercises, and moving attention from belching ${ }^{(10,11)}$. Putting attention on belching behavior increases the number while distraction reduces the frequency ${ }^{(3)}$. During speaking and during sleep, the number of belches is small or none ${ }^{(4)}$. There was the possibility that the subject, while gum chewing, would move attention from the situation of air swallow/supragastric belches, decreasing the number of belches and decreasing the sensation of discomfort.

The results showed that patients who complained of excessive belches had more air swallows but not gastric or supragastric belches, compared with the control group. Gum chewing caused an increase in air swallows in patients but not in controls, and in both groups an increase in saliva swallows and no alteration of gastric and supragastric belches frequency. It is possible that with the manometric/impedance catheter inside their upper digestive tract the subject refrained to swallow air and to belch. The results did not show any alteration in the number of belches during gum chewing.

Chewing gum causes an increase in saliva flow ${ }^{(6,17)}$, thus, as consequence, saliva swallowing is more frequent than without the gum. Increase in air swallowed was seen only in patients and 20 minutes after yogurt ingestion, without a correspondent increase in belching. It was possible to conclude from the results that gum chewing should not cause improvement or worsen the symptoms caused by troublesome belching.

Excessive belching may cause alterations of esophageal transit. It was described that after the swallow of a liquid bolus, the bolus head has a slower advance through the superior and middle esophagus and a shorter bolus presence time at the distal esophagus without alterations of esophageal contractions $^{(20)}$. Alterations in esophageal transit may be the consequence of inappropriate behavior of the patients and should be changed with treatment. The described transit alteration does not cause dysphagia ${ }^{(20)}$.

This investigation has some limitations. The number of patients involved should be higher, but the Roma III criteria are very strict and do not permit the inclusion of patients with questionable diagnosis. The evaluation of the flow of air or liquid through the esophagus was done for 20 minutes, a period that may be short but which should be enough to evaluate an abnormal flow of air or liquid. The reason for this registration duration was the discomfort caused by the manometric/impedance catheter. It is not possible to say that the impedance registration cause distraction or more attention by the patients. They understand that belching registration was being done during the examination. When patients with excessive belching are distracted, the incidence of belching is significantly reduced ${ }^{(3)}$. We can say from this investigation is that gum chewing is not a good way to avoid air swallow. As previously observed ${ }^{(2)}$, the incidence of gastric belches was similar in patients and controls but supragastric belches occurred exclusively in patients.

In conclusion, gum chewing causes an increase in saliva swallowing in patients with excessive belching and controls and an increase in air swallowing in patients with excessive belching 20 minutes after yogurt ingestion. Gum chewing did not increase or decrease the frequency of gastric or supragastric belches.

\section{Authors' contributions}

Silva ACV, Aprile LRO and Dantas RO, had participation in the planning, investigation and preparation of the manuscript.

Silva ACV, Aprile LRO, Dantas RO. Efeito da goma de mascar na deglutição de ar, deglutição de saliva e na eructação. Arq Gastroenterol. 2015,52(3):190-4.

RESUMO - Contexto - Eructação é um evento fisiológico que permite a eliminação de gás presente no estômago, geralmente não percebida como sintoma, situação identificada como eructação gástrica. Eructação supragástrica ocorre quando o ar deglutido não vai ao estômago, mas retorna do esôfago imediatamente após ser deglutido; situação que causa desconforto e limitações ao paciente. Objetivo - O objetivo desta investigação foi avaliar se goma de mascar aumenta a frequência de eructação gástrica e/ou supragástrica. Métodos - O trânsito de líquido e gás foi avaliado por impedância in 16 pacientes com queixas de eructação excessiva e 15 controles. O diagnóstico de eructação excessiva foi feito tendo em consideração os critérios descritos no Roma III. O trânsito pelo esôfago foi medido por sensores de impedância localizados a $5 \mathrm{~cm}, 10 \mathrm{~cm}, 15 \mathrm{~cm}$ e $20 \mathrm{~cm}$ do esfíncter inferior do esôfago. Os indivíduos foram avaliados sentados em uma cadeira durante um período basal de 20 minutos, outro período de 20 minutos após a ingestão de iogurte ( $200 \mathrm{~mL}, 190 \mathrm{kcal})$, mastigando ou não goma de mascar, e em outro período por mais 20 minutos no qual invertiam o fato de mastigarem ou não goma de mascar. Na eructação gástrica o ar vinha do estômago em direção proximal, e na eructação supragástrica o ar entrou no esôfago e foi imediatamente eliminado em direção proximal. A deglutição de ar foi caracterizada pelo aumento em pelo menos $50 \%$ do valor da impedância e a deglutição de saliva pela diminuição em pelo menos 50\% do valor da impedância, que progredia da parte proximal do esôfago para a parte distal. Resultados - No período basal a deglutição de ar foi mais frequente nos pacientes do que nos controles, e a deglutição de saliva mais frequente nos controles do que nos pacientes. Não houve diferenças na mediana entre os resultados de controles e pacientes no número de eructações gástricas e supragástricas. Em seis pacientes ocorreram eructações supragástricas, o que não aconteceu em nenhum controle. Entre os controles a ingestão de iogurte não alterou a frequência de deglutição de ar, deglutição de saliva, eructações gástricas e eructações supragástricas. No grupo de pacientes houve aumento da deglutição de ar. Mastigar a goma durante este período causou aumento da deglutição de saliva, nos dois grupos, sem alterações na frequência de deglutição de ar, eructação gástrica e eructação supragástrica. No período entre 20 e 40 minutos após a ingestão do iogurte, se a pessoa não mascava a goma, não havia mudança na frequência de deglutição de saliva, deglutição de ar, eructações gástricas e eructações supragástricas. Quando a pessoa mascava a goma, houve aumento da deglutição de saliva nos dois grupos e de deglutição de ar no grupo de pacientes. Conclusão - Goma de mascar causa aumento da deglutição de saliva em pacientes com eructações excessivas e controles, e aumento da deglutição de ar em pacientes 20 minutos após a ingestão de iogurte. Goma de mascar não aumenta ou diminui a frequência de eructação gástrica ou eructação supragástrica.

DESCRITORES - Eructação. Aerofagia. Deglutição. Esôfago. Saliva. 


\section{REFERENCES}

1. Bredenoord AJ. Excessive belching and aerophagia: two different disorders. Dis Esophagus. 2010;23(4):347-52.

2. Bredenoord AJ, Weusten BLAM, Sifrim D, Timmer R, Smout AJPM. Aerophagia gastric, and supragastric belching: a study using intraluminal electrical impedance monitoring. Gut. 2004;53(11):1561-5.

3. Bredenoord AJ, Weusten BLMA, Timmer R, Smout AJPM. Psycological factors affect the frequency of belching in patients with aerophagia. Am J Gastroenterol. 2006;101(12):2777-81.

4. Bredenoord AJ. Management of belching, hiccups, and aerophagia. Clin Gastroenterol Hepatol. 2013;11(1):6-12.

5. Cochrane NJ, Shen P, Byrne SJ, Walker GD, Adams GG, Yuan Y, et al. Remineralisation by chewing sugar-free gums in a randomised, controlled in situ trial including dietary intake and gauze to promote plaque formation. Caries Res 2012;46(2):147-55.

6. Dodds MW. The oral health benefits of chewing gum. J Ir Dent Ass. 2012;58(5): 253-61.

7. Ertas IE, Gungorduk K, Ozdemir A, Solmaz U, Dogan A, Yildirim Y. Influence of gum chewing on postoperative bowel activity after complete staging surgery for gynecological malignances: a randomized controlled trial. Gynecol Oncol. 2013;131(1):118-22.

8. Fu Y, Li X, Ma h, Yin W, Que K, Hu D, et al. Assessment of chewing sugar-free gums for oral debris reduction: a randomized controlled crossover clinical trial. Am J Dent. 2012;25(2):118-22.

9. Goudra BG, Singh PM, Carlin A, Manjunath AK, Reihmer J, Gouda GB, et al. Effect of gum chewing on the volume and $\mathrm{pH}$ of gastric contents: a perspective randomized study. Dig Dis Sci. 2015;60(4):979-83.

10. Hemmink GJM, Ten Cate L, Bredenoord AJ, Timmer R, Weusten BLAM, Smou AJPM. Speech therapy in patients with excessive supragastric belching - a pilot study. Neurogastroenterol Motil. 2010;22(1):24-e3.

11. Katzka DA. Simple office-based behavioral approach to patients with chronic belching. Dis Esophagus. 2013;26(6):570-3.

12. Kessing BF, Bredenoord AJ, Smout AJPM. Mechanisms of gastric and supragastric belching: a study using concurrent high-resolution manometry and impedance monitoring. Neurogastroenterol Motil. 2012;24(12): e573-9.
13. Kessing BF, Bredenoord AJ, Velosa M, Smout AJPM. Supragastric belches are the main determinants of troublesome belching symptoms in patients with gastro-oesophageal reflux disease. Aliment Pharmacol Ther. 2012;35(9):1073-9.

14. Kessing BF, Bredenoord AJ, Smout AJPM. The pathophysiology, diagnosis and treatment of excessive belching symptoms. Am J Gastroenterol 2014;109(8):1196-203.

15. Littel RC, Milliken GA, Stroup WW, Wolfinger RD, Scholenberg O. SAS for mixed models. Second Edition, Cary, NC: SAS Institute Inc., 2006.

16. Ohmure H, Takada H, Nagayama K, Sakiyama T, Tsubouchi H, Miyawaki S Mastication suppresses initial gastric emptying by modulating gastric activity. J Dent Res. 2012;91(3):293-8.

17. Plemons JM, Al-Hashimi I, Marek CL. Managing xerostomia and salivary gland hypofunction: executive summary of a report from the American Denta Association Council on Scientific Affairs. J Am Dent Assoc. 2014;145(8):867-73.

18. Saleh CMG, Bredenoord AJ. Utilization of esophageal function testing for the diagnosis of the rumination syndrome and belching disorders. Gastrointest Endoscopy Clin N Am. 2014;24(4):633-42.

19. Schall R. Estimation in generalized linear models with random effects. Biometrika. 1991;78:719-27.

20. Silva ACV, Aprile LRO, Dantas RO. Esophageal motility in troublesome belching. Arq Gastroenterol. 2013;50(2):107-10.

21. Tack J, Talley NJ, Camilleri M, Holtmann G, Hu P, Malagelada JR, et al. Functional gastroduodenal disorders. Gastroenterology. 2006;130(5):1466-79.

22. Tack J, Talley NJ. Transtornos gastroduodenais. Arq Gastroenterol 2012;49(Suppl 4):21-7.

23. Tazegül Pekin A, Kerimoglu OS, Dogan NU, Yilmaz SA, Kebapcilar AG, Gençoglu Bakbak BB, Celik C. Gum chewing reduces the time to first defaecation after pelvic surgery: A randomised controlled study. J Obstet Gynaecol. 2014;17:1-5.

24. Thabuis C, Cheng CY, Wang X, Pochat M, Han A, Miller L, et al. Effects of maltitol and xylitol chewing-gums on parameters involved in dental caries development. Eur J Paediatr Dent. 2013; 14(4):303-8.

25. Watemberg N, Matar M, Har-Gil M, Mahajnah M. The influence of excessive chewing gum use on headache frequency and severity among adolecents. Pediatr Neurol. 2014;50(1):69-72. 